\title{
SZENT ELEK LEGENDÁJA
}

\begin{abstract}
Szent Elek életének leírása a középkor egyik legismertebb és több nyelvre lefordított legendája. Jelen tanulmányban a legenda eredetét, a különböző nyelvű változatok jellegét (szír, görög, latin és népnyelvű változatok) és egyedi sajátosságait, valamint a magyar nyelvű hagyományt tárgyalom. Kutatásom során mindenekelőtt a legenda népszerűségére kerestem a választ, amely valószínűleg leginkább a változatok közös motívumkincsében és annak értelmezésében rejlik, amelynek bővülése és változása a legkorábbi szír változatoktól egészen a legelső népnyelvű változatokig megfigyelhető.
\end{abstract}

Kulcsszavak: Szent Elek, legenda, Edessa, Arkadios és Honorios, vándormotívum, kódex

I.

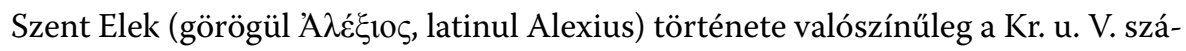
zadban keletkezett, és Szíriából ered. ${ }^{1}$ A szentélet tartalmát a legenda egyes változatai alapján az alábbiak szerint összegezhetjük: ${ }^{2}$ a szent apja jelentős vagyonú római szenátor vagy nemes ember volt, feleségével együtt istenfélő, gyermekük hosszú ideig nem született. A gyermekáldásért sokat imádkoztak Istenhez, s ez végül be is következett. A fiút Alexiosnak nevezték el, iskolába adták, ahol kitünt szorgalmával. Miután felnőtt, nemes származású lánnyal jegyezték el, de a házasság napja körül (a legendák itt eltérő időpontokat jegyeznek fel) elhagyta Rómát, hogy „felcserélje a földi életet az égivel”. Hajóra szállt, míg végül Edessába vetődött, ahol mindenét eladta, a pénzét szétosztotta a koldusok között, és attól fogva maga is koldusként élt tovább. Apja szolgákat küldött utána, akik Edessába is eljutottak, de nem ismerték fel, és alamizsnát adtak neki. (Ezt a jelenetet szinte mindegyik szöveg megörökíti, példaként arra, hogy Alexios, a nemes születésű, gazdag ifjú annyira megalázta magát az emberek előtt, hogy saját szolgáitól fogadott el pénzt.) A szent tizenhét évet élt ebben a városban, de végül életének szentsége lelepleződött az emberek előtt. A legenda innen különböző változatokban maradt fenn: az egyik változat szerint Alexios Edessában megbetegedik, az ottani templomfelügyelö ápolja, de a szent végül meghal. Edessában temetik el, majd a temetés után a föpap (miután értesül a szentről) felkeresi a sírt, ahol csak a leplet találja, amelybe a testet a temetéskor becsavarták. Ez a jelenet nyilvánvaló utalás a Jézus halála után történtekre. A legenda másik változata szerint (amely a szír eredeti görög átdolgozása) Alexios lelepleződése után elmenekül Edessából, és Tarsosba indul Szent Pál iránti tisztelete miatt. Hajója viszont viharba keveredik, és Rómában köt ki. Ekkor a szent elhatározza, hogy

${ }^{1}$ Illés Gy.: Szent Elek legendáink és az Elek legenda forrásai. Budapest 1913. 8 sk.

2 Illés: i. m. (1. jegyz.) 10 sk. Vö. Madas E.: Szent Elek. In: Diós I. - Viczián J. (szerk.): Magyar Katolikus Lexikon III. Budapest 1997. 
a szüleinél kér majd szállást, és náluk fog lakni remeteként és koldusként. A családjából és a szolgák közül senki nem ismeri fel, de befogadják, és tizenhét évet tölt el náluk. A szolgák folyamatos bántalmazását is eltüri, közben pedig szüntelenül sanyargatja a testét. Mikor közeledni érzi halálát, Alexios íróeszközt és írószerszámot kér, leírja életét és olyan „titkokat”, amelyekről családja ráismerhet, majd az írást kezében tartva meghal. Égi szózat hallatszik a templomban, hogy keressék meg Isten emberét a városban. Végül megtalálják őt a szülei házában, elolvassák az életéről leírtakat, ráismernek, és megtudják, hogy valóban szent életet élt. Családja elsiratja, ravatalánál pedig csodák történnek. Ünnepnapja ma a római katolikus egyházban július 17-e, a görög katolikusban korábban február 17-e volt, később március 17-e lett, amely a hagyomány szerint temetésének napja.

\section{II.}

A legenda szír eredetü. Felmerült, hogy talán Edessában jegyezték le, sőt az is, hogy esetleg az a templomszolga írta le a szent történetét, aki Alexiost ellátta betegsége idején. ${ }^{3}$ A felvetés bizonyíthatatlan, másfelöl igaz is lehet. A nyolc ismert szír szövegből hat a British Museumban, kettő a párizsi Bibliothèque Nationalban található. ${ }^{4} \mathrm{~A}$ szír nyelvü legendákat két, egymástól jelentősen különböző csoportba oszthatjuk. ${ }^{5} \mathrm{Az}$ első csoportba azon legendák tartoznak, amelyek az V. század legvégén és a VI. század folyamán keletkeztek. Három, nagyjából egy időben keletkezett szöveg lényegi elemekben nem tér el egymástól, mindhárom a szent edessai haláláig írja le a történteket. ${ }^{6}$ A legkorábbi szír változat (az Add. 17177 jelzetű kódexben található szöveg) meglehetősen egyszerű a későbbiekhez képest, ${ }^{7}$ ennek ellenére megállapítható róla, hogy másolat, valószínüleg a szent halála után készült első kéziratról. ${ }^{8}$ Mivel a legenda változatai a történeti környezet kapcsán, amelyben Alexios élt, az V. század végét írják le, valószínüleg ebben a században keletkezhetett a legenda eredeti, mára már elveszett leirata is. ${ }^{9}$ Ebben a szövegváltozatban (amely a későbbiekhez képest igen rövid) Alexios búcsú nélkül, házassága napja előtt hagyja el Rómát, egyszerüen kilovagol a kikötőbe, majd onnan

${ }^{3}$ Illés: i. m. (1. jegyz.) $10 \mathrm{sk}$.

${ }^{4}$ A. Amiaud: La légende syriaque de Saint Alexis. L'homme de Dieu. Paris 1889. 1.

${ }^{5}$ C. E. Stebbins: Les origines de la légende de Saint Alexis. RPh 51 (1973) 499.

${ }^{6}$ A British Museumban található Add. 17177, Add. 14644 és Add. 12160 jelzetü kódexekben található szír nyelvü szövegek.

7 Stebbins: i. m. (5. jegyz.) 499.

${ }^{8}$ Illés: i. m. (1. jegyz.) 9.

9 Illés: i. m. (1. jegyz.) 10: „Az első kéziratok a szent halálát Mar Roubola püspökségére teszik, ez pedig 412 és 435 között volt püspök, a legenda sem lehet sokkal későbbi [...], nagyon is plauzibilis az az általánosan elfogadott vélemény, hogy a legenda 450 és 475 között keletkezett." 
elhajózik Edessába. ${ }^{10} \mathrm{~A}$ templomszolgának háromszoros álombeli jelenés adja tudtára, hogy templomában szent életű ember tartózkodik, aki nappal a templom bejáratában koldul, éjszaka pedig az előtérbe húzódva, virrasztva imádkozik. A templomszolga, miután végre hajlandó a jelenés kérésének eleget tenni, megkeresi és kifaggatja Alexiost az életéről. A szent - származását és nevét kivéve - mindent részletesen elmesél neki. Betegsége idején ez a templomszolga ápolja őt hű kitartással. Mikor azonban Alexios meghal, épp nem tartózkodik mellette, ezért tudják a szent holttestét a szolgálók a tudta nélkül elvinni és eltemetni. A templomszolga Alexios szállására visszatérve csak hűlt helyét találja a szentnek, ezért a temetőbe siet. Útközben találkozik a püspökkel, akinek mindent elmond a szentről, ezután pedig együtt mennek a temetőbe. Ott találják a szolgálókat, akik bevallják, hogy eltemették a testet, de mikor kibontják a sírt, már csak a halotti leplet találják benne.

A második csoportba négy olyan kézirat tartozik, amelyek a IX. és a XIII. század között keletkeztek. Ezek a szövegek megegyeznek a görög-latin legendaváltozatokkal, melyek szerint a szent visszatér Rómába, a szülei házába, ahol koldusként él, míg végül utoléri a halál. ${ }^{11}$

III.

A második, „görög-típusú” legendának is nevezhető változat már jelentősen bővült az eredeti szírhez képest. A szövegnek ilyen jellegű változása és bővülése nem kizárólag a görög nyelvű változatban ment végbe, hanem a szír legendák között is találunk rá példát. ${ }^{12} \mathrm{Ez}$ a változat - a bővülés mellett - néhány mozzanatban meg is változott, sőt, a főszereplő Alexioson kívül a többi szereplő is nevet kap (apja Euphémianos, anyja pedig Aglais). Alexios elveszi feleségül a számára kijelölt menyasszonyt, majd a nászéjszakán elbúcsúzik tőle: titkokat oszt meg vele (valószínűleg a szűzies, tiszta életről), végül övét, kendőjét és gyürüjét hátrahagyja nála, melyek így később a ráismerés kellékeivé válnak, és elhajózik Rómából. Hosszabb út után eljut Edessába, ahol a Szűz Mária-templomban Jézus-képmást őriznek. A képmásra vonatkozóan is számos legendaváltozat létezik, amelyek szerint Edessa egykori királyának, Abgarnak vagy Abgarusnak Jézus Krisztus kendőt küldött, amelyen rajta volt arclenyomata. Ezt a ma is tisztelt szent tárgyat Szent Mandylionnak nevezik, amely sokban emlékeztet Veronika kendőjére. ${ }^{13}$ (Érdekes, hogy az ófrancia verses változat szerint Alexios éppen e miatt a kendő miatt

${ }^{10}$ Ezt a szír nyelvű szöveget Arthur Amiaud adta ki és fordította le franciára a British Museumban található Add. 17177 jelzetü kézirat alapján.

11 Stebbins: i. m. (5. jegyz.) 501.

12 Amiaud: i. m. (4. jegyz.) 50 feltételezi (pontosabban nem zárja ki), hogy a bővülés először nem a szír nyelvű legendákban jelent meg, hanem a görögben, amelyek így a későbbi, hosszabb szír változat alapjait képezik.

${ }^{13}$ Puskás B.: A nem kézzel festett Krisztus-arc ábrázolások és a kárpáti régió középkori ikonfestészete. Athanasia 20 (2005) 50-51. 
választja Edessát utazása céljául. ${ }^{14}$ ) Mikor a szent már tizenhét évet eltöltött a városban, a templombeli képmás megszólal, és tudtára adja a sekrestyésnek, hogy szent ember lakik a templom falai között. A templomszolga erre be akarja vezetni a közösségbe, de Alexios megrémül, és újra hajóra száll, ezúttal Szent Pál nyomán Tarsosba igyekszik eljutni. A változat sajátossága, hogy a szent családját is bemutatja, és tetteiket azok után is részletezi, hogy Alexios elhagyta otthonát. Mindez nyilván arra is szolgált, hogy a történetet „olvasmányosabbá”, befogadhatóbbá tegye, de kiderül belőle az is, hogy Alexios szent életvitele olyan nagy hatással volt családjára, hogy vezeklésül, és fiuk elvesztése felett érzett bánatukban szülei is gyakorlatilag Istennek szentelték életüket. A szent felesége a szülőkkel lakik, és szűzies életet él. Alexios, mikor visszatér Rómába, a szülei házában kap szállást, ahol testének sanyargatása mellett a szolgák bántásait is el kell viselnie. Halála után a feleségének adott tárgyakról ismernek rá, amelyeket megemlít életírásában is. Felismerésekor Róma „királyai” is jelen vannak, sőt egy érsek is, akik tanúsítják, hogy Alexios valóban szent életet élt, annál is inkább, mert csak ők tudják elvenni a halott kezéből az életéről készített írást. Felravatalozzák, ahol a legendákban szokásos csodálatos gyógyulások történnek, majd eltemetik a Szent Bonifác-templomban, amelyet később róla neveznek el.

Edessa már az I. századtól kezdve keresztény város volt, majd a perzsa és arab hódítások után a várost a keresztes hadjáratok tették újra keresztény többségüvé a XI. században. ${ }^{15}$ Valószínűleg ebben az időben, zarándokok útján juthatott el a legenda Bizáncba, ahol később a különböző szentlegendák (pl. Kunyhós Szent János) hatására bővült ki. ${ }^{16}$ A görög szöveg legrégebbi változatát valószínüleg a IX. században Josephus Hymnographius jegyezhette le, ${ }^{17}$ aki himnuszgyüjteményt állított össze, amely többségében négy versszakból álló költeményeket tartalmaz. A válogatás Szent Elek életéröl is tartalmaz három verset, amelyeket latinra a bollandisták fordítottak és adtak ki Velencében 1639-ben. ${ }^{18}$ Symeón Metaphrastésnek is tulajdonítanak egy XII. századi változatot, amely több görög és latin változat kiindulópontja: előbb Agapios görög, majd Laurentius Surius latin nyelvű legendagyüjteményében találjuk meg. ${ }^{19}$ A legendát tartalmazó kódex ma az Osztrák Nemzeti Könyvtárban található (ÖNB Ms. 153). Az Agapiosnak tulajdo-

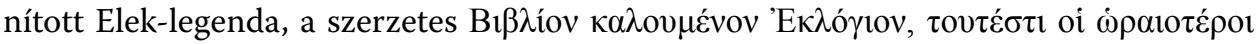

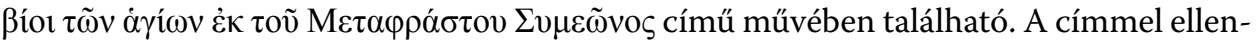

${ }^{14}$ Vö. Vie de Saint Alexis XVIII. versszak. G. R. Mermier - S. M. White (éd.): La vie de Saint Alexis. Poème du XI ${ }^{\mathrm{e}}$ siècle. Paris 1983.

15 Stebbins: i. m. (5. jegyz.) 502.

16 Stebbins: i. m. (5. jegyz.) 502.

17 C. Storey: An Annotated Bibliography and Guide to Alexis Studies (La vie de Saint Alexis). Histoire des idées et critique littéraire 251 (1987) 65, illetve Stebbins: i. m. (5. jegyz.) 683.

18 Storey: i. m. (17. jegyz.) 65.

19 L. Surius: De probatis Sanctorum Vitis. Cologne 1618; Vö. M. Rösler: Die Fassungen der Alexiuslegende mit besonderer Berücksichtigung der mittelenglischen Versionen. Wiener Beiträge zur englischen Philologie 21 (1905) 19. 
tétben ez a variáns jelentősen eltér a Metaphrastés-féle változattól. ${ }^{20}$ A legenda névtelen szerző műveként is fennmaradt görög nyelven egy müncheni kódexben (Cod. Gr. 3).

A görög legendák ezen változata a már említett szír legenda bővülésére vezethető vissza. ${ }^{21}$ A szöveg bővülésének időszaka többé-kevésbé meghatározható: ${ }^{22}$ az említett edessai Mária-templom a VI. század folyamán épült, és a IX. századra már kialakult a legenda azon változata, amelyre nagy hatással lehetett Johannes Calybita legendája. ${ }^{23}$ Kunyhós Szent János legendája ugyanis csaknem ugyanazokból az elemekből épül fel, mint Alexiosé (a szent anyja sokáig gyermektelen volt; hetente csak egyszer vett magához élelmet; a Szűzanya felfedte az emberek előtt szent életvitelét; koldusként élt szülei háza előtt; a szolgák rosszul bántak vele; halála után kiderültek szent cselekedetei, stb.). Mivel a szerkezet más szentéletekben is fellelhető, különösen fontos az eredet kérdése. Arthur Amiaud szerint (aki elsősorban a szír változatokat kutatta) valamiféle „bizánci eredetiről” lehet szó, ${ }^{24}$ véleménye szerint a későbbi szír szövegek fele görög hatást mutat. Margarete Rösler - Amiaud felvetései alapján - a „bizánci eredeti” legfontosabb jellegzetességeiként az alábbiakat emelte ki: ${ }^{25} 1$. Arkadios és Honorios császárok a történet elején és végén egyaránt szerepelnek; 2 . A Rómában bevett pontifex maximus tisztségnév helyett az ỏ $\rho \chi \imath \pi i ́ \sigma \kappa о \pi о \varsigma$ (többé-kevésbé az érseknek felel meg) használata; 3 . Az esküvő és a temetés egyaránt a Szent Péter-templomban történik; 4. Meneküléskor a vőfély ( $\left.\pi \alpha \rho \alpha v v \mu \varphi{ }^{\prime} \varsigma\right)$ kíséri ki Alexiost Róma kikötőjébe.

Ezek a meghatározó tartalmi elemei (egymástól függetlenül) Josephus Hymnographius himnuszainak, két szír szövegváltozatnak, illetve a Rösler által kiadott görög nyelvű, „rövidebb” feldolgozásnak (Marcianus Cod VII, 33). Bár Rösler kiemeli, hogy mindezekből esetenként kevés maradt meg az egyes változatokban, például a vőfély alakja kiesik, illetve a Szent Péter-templomban tartott ceremóniák átköltöznek a Szent Bonifác-templomba. ${ }^{26}$

A Symeón Metaphrastés által írt legenda sajátosságai is megtalálhatóak későbbi görög és latin Elek-legendákban. Az alábbi elemek tartoznak ide: ${ }^{27} 1$. A vőfély hiánya; 2. Alexios Arkadios és Honorios császárok uralkodásának idején élt, és halála napjának pontos időpontja is ismert: március 17. A későbbi legendákban a császárok neve (akár datálási célból) és tevékeny szerepük leírása többnyire megjelenik.

20 Stebbins: i. m. (5. jegyz.) 684.

${ }^{21}$ Illés: i. m. (1. jegyz.) 13.

${ }^{22}$ Illés: i. m. (1. jegyz.) 12; M. Rösler: Alexiusprobleme. Zeitschrift für romanische Philologie 53 (1933) 517.

${ }^{23}$ Josephus Calybita, magyarul Kunyhós Szent János, hitvalló (meghalt 450 körül). Gazdag családba született, sokat tanult, majd érezvén az isteni hívást, szerzetesnek állt. Később szülei háza előtt lakott koldusként egy kis kunyhóban, innét származik magyar neve is. Szülei nem ismerték fel, de János halála előtt felfedte magát nekik. Vö. Stebbins: i. m. (5. jegyz.) 502; Rösler: i. m. (22. jegyz.) 518.

${ }^{24}$ Amiaud: i. m. (4. jegyz.) 49; Rösler: i. m. (19. jegyz.) 7; Rösler: i. m. (22. jegyz.) 517.

${ }^{25}$ Rösler: i. m. (19. jegyz.) 9.

${ }^{26}$ Rösler: i. m. (22. jegyz.) 508-511. Marcianus Cod VII., 33.

27 Rösler: i. m. (19. jegyz.) 13. 
Az alábbiakban két görög nyelvü legendaváltozatot ismertetek röviden. Az első a Rösler által 1933-ban közölt, kézirata a velencei könyvtárban található. A másik szövegváltozat kritikai kiadását pedig a bollandisták adták közre (1900) három kódex alapján (Parisinus Graec. 1538 a X. századból; Vaticanus Graec. 866 a XII. századból; Baroccianus Graec. 146 a XV. századból).

A Rösler-féle szöveg a rövidebb legendaváltozatok csoportjába tartozik, és feltehetőleg a XII. században keletkezett. ${ }^{28}$ Szóhasználata közel áll a klasszikus göröghöz, sok esetben az Újszövetség szókincséből is merít. ${ }^{29}$ Szír kölcsönszavak nem találhatóak benne, ezzel szemben az Amiaud által vizsgált legrégebbi szír szövegben három görög szó

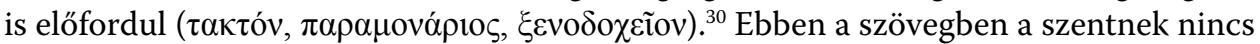
neve, egyszerüen „Isten embereként” hivatkoznak rá. A történet elemei megegyeznek a szír változatéval: a főhőst a vőfély kíséri ki a kikötőbe, Edessába jutva a Mária-templomban húzódik meg, imádkozik és koldul, az alamizsnából azonban csak ételt vásárol, vizet a helyi forrásból vesz magához. A templomszolga háromszoros álombeli jelenés után végül az előcsarnokból bevezeti a templomba, ahol a szent elmondja neki az életét, majd később megbetegedik és meghal. A cselekmény alkotórészei mindvégig igen valószerűek, szinte csak a sírból való eltűnés tekinthető „csodás elemnek”.

A másik szövegváltozat egyik hagyományozója egy viszonylag korai, X. századra keltezett párizsi kódex. A kézirat keletkezésének ideje miatt felvetődött, hogy akár összefüggés lehet a legendaváltozat és Sergios metropolita Rómába érkezése között. A püspök ugyanis igyekezett elterjeszteni Alexios tiszteletét a Városban. ${ }^{31}$ Erre utalhat-

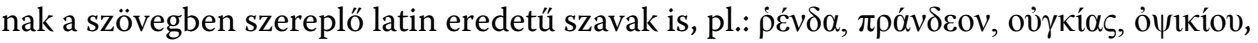
stb. Természetesen ezek a szavak másképp is belekerülhettek a szövegbe, Rösler említi, hogy bizonyos legendaváltozatokat latinból fordítottak vissza görögre, ${ }^{32}$ ami ugyancsak indokolhatja a latin elemek megjelenését. Ilyen elem lehet például a menyasszonyi búcsújelenetben a $\rho \varepsilon ́ v \delta \alpha$ (öv) szó megjelenése. A legkorábbi görög szövegekben ugyanis $\zeta \omega ́ v \eta$ áll ezen a helyen: $\varepsilon i \zeta \zeta \omega ́ v \eta v \delta ı \delta o ́ v \alpha ı$ vagyis „tüpénzt adni” értelemben (tehát Alexios mintegy „visszafizeti” a hozományt). ${ }^{33}$ A prosmonarios szerepe csökken, csak az isteni akarat végrehajtója lesz; a királyoké viszont jelentősen megnő: már nemcsak a történet kronológiai keretét határozzák meg a neveik, hanem tevékeny részesei lesznek a szent halála utáni történéseknek. Az élettörténetet tartalmazó írást ugyanis csak a királyok tudják kivenni Alexios kezéből, mintegy bizonyítékául annak, hogy ők voltak Róma „legjámborabb” ( $\theta \varepsilon \imath$ co $\alpha$ ¿ı) uralkodói.

Alexios születési helye is kérdéses. Nem egyértelmű ugyanis, hogy a szír legendákban melyik „Róma” szerepelt. A C(a)poli(m) szótöredék legalább kétféleképpen egé-

${ }^{28}$ Rösler: i. m. (22. jegyz.) 508-511.

${ }^{29}$ Rösler: i. m. (22. jegyz.) 515.

${ }^{30}$ Rösler: i. m. (22. jegyz.) 515.

${ }^{31}$ B. de Gaiffier: Note sur la date de la Légende grecque de S. Alexis. Annalecta Bollandiana 19 (1900) 255.

32 Rösler: i. m. (22. jegyz.) 522.

33 Rösler: i. m. (22. jegyz.) 522. 
szíthető ki: ha az itáliai Rómába helyezzük Alexios születési helyét, akkor a Capitolium rövidítése. Ha a szerző az Új Rómára, vagyis Bizáncra gondolt, akkor Constantinopolis a feloldás. Utóbbi a fent említett Kunyhós Szent János legendájának hatását mutathatja. ${ }^{34}$

A X. századtól több görög és latin szövegben szerepel Szent Bonifác kápolnája: ott házasodott meg Alexios, és ugyanott temették el. A kifejezetten görög jellegű Szent Bonifác-kultusz Rómában nem terjedt el, de a Sergios metropolitával az Aventinusra érkező görög szerzetesek templomukat Bonifácról nevezték el. ${ }^{35}$ Szent Bonifác jelentősége a görögök szemében vetekedett a római Szent Péterével. Ez az egyik oka annak, hogy a későbbi scriptorok Bonifác templomába helyezik a rituálékat. Alátámasztja mindezt, hogy míg Szent Péter alakja igen ritkán szerepel görög szövegekben (leginkább a temetési rituálék kapcsán szokták említeni), Szent Bonifác annál gyakrabban, különösen a házassággal kapcsolatban. ${ }^{36}$ A szerzetesek közösségének munkája nyomán honosodott meg a Rómában addig ismeretlen legenda és kultusz, amely a XII. századra meglepő gyorsasággal terjedt el a városban.

IV.

A latin nyelvű változatoknak köszönhetően a legenda egyre elterjedtebb és népszerủbb lett. A latin „vulgátának” hatása az is, hogy a legtöbb újlatin nyelven szinte a legkorábbi kéziratok között találjuk meg Alexios legendáját. Feltételezhető ugyanakkor, hogy minden további, X. század után keletkezett latin (és görög) legenda görög forráson alapszik. ${ }^{37}$ Erre magyarázatul szolgálhatnak az alábbi tények: ${ }^{38} 1$. A szereplők nevei görögök (kivéve Alexios feleségét, aki legelőször a latin nyelvű legendákban kap nevet); 2. Alexios legendája és kultusza egészen a X. századig ismeretlen volt Rómában (lásd fent a görög szerzetesek megtelepedéséről írottakat); ${ }^{39} 3$. A görög rítusban nagy szerepet kap a szentképek tisztelete. 4. Egyes görög, latin és később újlatin nyelven íródott legendaváltozatok Alexios halálát nagypéntekre teszik, ez pedig közelebb esik a görög katolikus egyházban a szent ünnepnapjához (március 17.), mint a római katolikus egyház által meghatározotthoz (július 17.). ${ }^{40}$

${ }^{34}$ Rösler: i. m. (22. jegyz.) 526.

35 de Gaiffier: i. m. (31. jegyz.) 254 sk.

${ }^{36}$ de Gaiffier: i. m. (31. jegyz.) 254-255.

37 Rösler: i. m. (19. jegyz.) 2.

38 Rösler: i. m. (19. jegyz.) 2.

39 de Gaiffier: i. m. (31. jegyz.) 255; Stebbins: i. m. (5. jegyz.) 498 és 505.

40 Valószínű, hogy ez Jézus Krisztus életéből vett elem, akárcsak a szír és rövidebb görög legendákban található üres sír motívum. Rösler i. m. (19. jegyz.) 7 szerint félreértésről lehet szó, ugyanis a görög legendákban szereplő $\pi \alpha \rho \alpha \sigma \kappa \varepsilon v \eta ́$ szó általánosságban jelenthet pénteket, így a görög változatokban nem is jelent(het) nagypénteket. Az angol és portugál változatokban viszont egyértelműen nagypéntekről van szó. 
A legismertebb variánst az Acta Sanctorum őrizte meg, amelynek egy IX. századi kézirat lehetett az alapja. ${ }^{41} \mathrm{Ez}$ a szöveg sok későbbi latin változatnak vált forrásává, közülük a leghíresebb a Legenda Aurea, Jacobus de Voragine XIII. századi legendagyüjteménye. ${ }^{42}$ Fontos új mozzanat a szereplők nevének etimológiája, amely először a latin nyelvü szövegben jelenik meg. Így Alexios nevét az ógörög ả $\lambda \hat{\varepsilon} \xi \omega$ „távol tartja magától

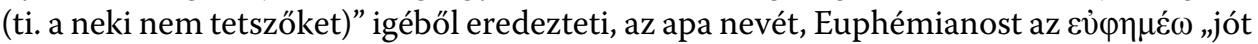
jósol” igéből, anyja nevét (Aglais) pedig az $\alpha \gamma \lambda \alpha o ́ \varsigma$ „dicső” melléknévből. A menyasszony neve is elsőként a latin változatokban bukkan fel, aligha meglepő, hogy egyedül ő kap latin nevet: Adriatica.

A királyokkal együtt Innocentius pápa is megjelenik Alexios ravatalánál, aki a scriptor kiegészítéseként kerülhetett bele a szövegbe, valószínűleg a görög variánsokban szereplő Markianos érsek helyett. A Legenda Aurea mellett a másik legfontosabb latin nyelvű Elek-legenda az ún. „müncheni” szöveg. ${ }^{43}$ A két szöveg a történet szempontjából megegyezik, inkább a nézőpontjuk az, amely megkülönbözteti őket egymástól. A Legenda Aurea inkább az egyházi személyek méltóságát tartja szem előtt, az egyház mindenhatóságára helyezi a hangsúlyt, és a szent aszketizmusát domborítja ki. A müncheni szöveg a személyesebb, érzelmekben gazdag jelenetekre irányítja a figyelmet, azokat dolgozza ki nagy gonddal (pl. a feleség bánatát és gyengéd kapcsolatát férjével). Itt a feleség az, aki ki tudja venni Alexios kezéből az írást, amelyet sem szüleinek, sem pedig az egyházi embereknek nem adott oda. Halála után a szent mellé temetik el, s amikor elhelyezik holttestét a közös sírba, a férfi csontjai helyet adva a szeretett feleség maradványainak, odébb húzódnak, így tanúsítva, hogy milyen megható és szép kapcsolat volt kettejük között még úgy is, hogy szűzen éltek a házasságban.

A latin nyelvü szövegek népszerüsége miatt több újlatin nyelv korai írásos emlékeiben megjelenik a legenda, ismertek drámai változatok is, például a spanyol Augustin Moreto y Cabana drámája La vida de San Alexo címen 1654-ből. Az egyik legkorábbi és egyben legismertebb újlatin változat az ófrancia nyelven versbe szedett Vie de Saint Alexis, melynek keletkezése a XI. századra tehető. ${ }^{44}$ Formája nem egyedi, hiszen már latin nyelven is létezett két hexameteres költemény. A százhuszonöt versszakból álló legenda 10 szótagú sorokból, dekaszillabusokból áll. A tulajdonnevek „franciás” átírásban szerepelnek, így Alexiosból Alexis lesz, apjának neve Eufémien, Edessa Alsis, Laodicea pedig Lalice néven szerepel. Az anya és a feleség nevét a vers nem említi. A római és az edessai szökések egyaránt az éjszaka közepén történnek: „Au milieu de la nuit il s'enfuit du pays” (15. vsz.) és „Au milieu de la nuit il s'enfuit de la cité” (38. vsz.). Alexist a hónap 7. napján temetik el a Szent Bonifác-templomban, ahol jelen van Róma két császára és

${ }^{41}$ Illés: i. m. (1. jegyz.) 21.

42 Illés: i. m. (1. jegyz.) 29.

${ }^{43}$ Illés: i. m. (1. jegyz.) 25 nem említi a kódex jelzetszámát, de H. F. Massmann: Sanct Alexius Leben in acht gereimten mittelhochdeutschen Behandlungen. Quedlinburg und Leipzig 1843. 157 szerint feltehetően a Cod. Ratisbon civ. LXX vagy a Cod. Scheftlar 138 jöhet számításba.

44 N. Cartlidge: The St. Albans Psalter. In: Medieval Marriage: Literary Approaches, 1100-1300. Cambridge (1997) 79. 
a pápa is. A mủ legkorábbi ránk maradt változata a XII. századi, angliai St. Albansről elnevezett zsoltároskönyvben található. ${ }^{45} \mathrm{~A}$ gazdagon illusztrált imádságoskönyv érdekessége, hogy az ófrancia chanson latin zsoltárok között maradt fenn ${ }^{46}$ Mivel tulajdonosának a Merkyatéból származó Christinát tartják, aki maga is szűzies életéről volt ismert, és későbbi házasságában is megtartóztatta magát, valószínủleg az ő igazolására és dicséretére került a költemény a kódexbe. ${ }^{47}$

H. F. Massmann nyolc korai német nyelvủ Elek-legendát ismertet, amelyek a XII. és XV. század között keletkeztek. ${ }^{48} \mathrm{~A}$ szövegek tartalmazzák Euphémianos kegyes cselekedeteit: a rászorulóknak biztosított három asztalt; Alexius hosszú keleti útját, amelynek során Jeruzsálemben is több évet tölt el; és a sírjánál bekövetkező számos csodát. ${ }^{49}$ Ezek a változatok Alexios és a felesége, Adriatika (egyes változatokban Sabina) közötti gyengéd kapcsolatot emelik ki. A feleség a férjét hűségesen várja haza, halála után pedig elsiratja. Mikor Adriatika meghal, Alexios mellé temetik el, akinek csontjai odébb húzódnak, hogy helyet adjanak felesége maradványainak..$^{50}$

\section{V.}

A legenda magyar nyelven is elterjedt, megtalálhatjuk a Peer-, Nádor-, Lobkowicz-, Kazinczy-, Érdy- és Tihanyi-kódexben is. ${ }^{51} \mathrm{~A}$ szövegek tartalmukban igen közel állnak egymáshoz, így felmerül a kérdés, vajon volt-e közös forrásuk. Jóllehet a Legenda Aureá-hoz képest egyaránt megfigyelhetünk hasonlóságokat és eltéréseket, az elválasztó hibák jól elkülönülő egységet mutatnak. Az összes magyar változatból hiányzik a feleség neve és a szereplők nevének népetimológiája, jóllehet ezek valamennyi latin szövegben megtalálhatóak. Ezek alapján feltételezhetünk egy köztes változatot a Legenda Aurea és a fennmaradt hat magyar fordítás között, amely akár a Legendából készített latin nyelvü egyszerüsített változat, akár egy magyar nyelvü „ősfordítás” lehetett. ${ }^{52}$ Mindenesetre ilyen változat latinul nem maradt ránk..$^{53}$

Mivel a hat magyar szöveg tartalmilag érdemben nem különbözik egymástól, a fordítások leginkább a nyelvi pontosság és a stílus szempontjából vethetők össze. Öszszességében elmondható, hogy a szövegekre hatott az élő beszéd (pl. mondatszerkezet, jelzők megválasztása, költői képek stb.), de emellett olykor magyartalan latinizmus is jellemzi őket. Az alábbiakban Kőrös Kata kutatási eredményeit összegzem, aki a magyar

${ }^{45}$ Cartlidge: i. m. (44. jegyz.) 76.

${ }^{46}$ Cartlidge: i. m. (44. jegyz.) 78.

${ }^{47}$ Cartlidge: i. m. (44. jegyz.) 76-77.

${ }^{48}$ Massmann: i. m. (43. jegyz.) 1 sk.

${ }^{49}$ Massmann: i. m. (43. jegyz.) 15-19.

${ }^{50}$ Massmann: i. m. (43. jegyz.) 19.

${ }^{51}$ Illés: i. m. (1. jegyz.) 31.

${ }^{52}$ Illés: i. m. (1. jegyz.) 32.

${ }^{53}$ Illés: i. m. (1. jegyz.) 32. 
fordításokat abból kiindulva elemezte, hogy az Elek-legenda milyen tartalmú szövegekkel szerepel egy kódexben, illetve milyen stilisztikai jellegzetességei vannak. ${ }^{54} \mathrm{Nem}$ közömbös ugyanis, hogy a legendát tartalmazó kódex szövegeit milyen igény szerint válogatták össze (imádságos könyvnek készült-e, elmélkedő jellegét kívánták-e erősíteni, vagy a legendák példaadó funkcióját akarták-e kihasználni), mert mindez biztosan hatással volt arra is, hogy az Elek-legendát miként fordították, hogyan igazították stiláris értelemben is a kódex egészét jellemző rendező szempontok szerint.

A legkorábban keletkezett változatot feltehetően a Nádor-kódex (Cod. Hung. 1) őrizte meg, 1508-ból. A kódexben az Elek-legenda mellett passiók, imádságok, elmélkedések és egyéb legendák szerepelnek. Akadt, aki szerint a felsoroltak közül ez a legsikerültebb fordítás. ${ }^{55} \mathrm{~A}$ szöveget valószínűleg olvasásra szánták, és mivel sok benne a magyarázat, inkább tűnhet élő beszéd jellegűnek, mint a latin eredeti. A latinizmusok mellett latin szavak is felbukkannak, amelyeket nem fordított le a szerző, vagy, mert nem találta a magyar megfelelőjét (esetleg még nem létezett), vagy a latin szó ebben a közegben a szókincs része lehetett. A fordító saját befejezést írt a szöveghez, Elek halálának évét pedig 338-ra teszi. ${ }^{56}$ A valószínűleg ugyancsak a XVI. század elején keletkezett Peer-kódexben (MNY 12) legendák, imádságok és énekek között található a szentélet. A szöveg csonka, eleje hiányzik. Egyetérthetünk azzal az állásponttal, hogy a kódex szövege a vélt keletkezési időhöz képest korábbi nyelvállapotot tükröz, így régies nyelvezetünek mondható. Ez a fordítás követi leghívebben a Legenda Aureát, olyannyira, hogy nemcsak a költői képek pontos fordítására, hanem a frázisok, sőt gyakran még a szórend megtartására is törekszik. Ettől eltekintve azonban a tömör latin kifejezéséket szabadon magyarosítja, és igyekszik minden latin szó magyar megfelelőjét megtalálni. Nem mentes a latinizmusoktól, különösen azért nem, mert kifejezetten a latin eredetit törekszik követni. Ez tükröződik időnként a mondatszerkezetekben is, s ennek hatására a szöveg helyenként nehezen érthetővé válik. A fordító saját befejezéssel zárja a legendát, Szent Elek halálát pedig 398. Szent Jakab havának 16. napjára teszi. ${ }^{57}$ A Lobkowicz-kódexet (VI. Fg. 30) imádságok, elmélkedések, legendák alkotják. A kézirat szerkesztését alapvetően meghatározta, hogy valószínűleg egy előkelő hölgynek, talán egy apáca rendfőnöknőnek (akiről feltételezik, hogy klarissza lehetett) állították össze. ${ }^{58} \mathrm{Ez} \mathrm{a}$ változat a leghosszabb az összes magyar fordítás közül, a fordító ugyanis saját megjegyzéseivel is bővítette a legenda szövegét, továbbá maga is írt bele fohászokat, a meglévő imádságokat pedig nagy műgonddal fordította le. Viszonylag nagy szabadságot engedett

${ }^{54}$ Körös K.: Szent Elek legendájának fordításai kódex irodalmunkban. In: Plaustrum seculi IV. Az ELTE BTK Régi Magyar Irodalomtörténeti Tanszékén 2006. április 22-én rendezett konferencia szerkesztett anyaga. Szerk.: Bárczi I. Hozzáférhető: http://sermones.elte.hu/page/346tan_plaus_kkata.html (megtekintve: 2016. 04. 02.)

55 Körös Toldy Ferencet említi.

56 Illés: i. m. (1. jegyz.) 38.

57 Illés: i. m. (1. jegyz.) 36.

${ }^{58}$ Kacskovics-Reményi Andrea közlése: http://nyelvemlekek.oszk.hu/adatlap/lobkowiczkodex (megtekintve: 2016. 04.02.). 
meg magának a szöveg egyes részeinek tolmácsolásában: a számára lényegtelennek tűnő események és helyek felett átsiklott, az érdekes részeket ezzel szemben némiképp kibővítette. A korábbi és későbbi változatokhoz képest a szereplőinek több helyen enged megszólalást. Saját befejezéssel zárja a legendát, de nem említi meg Elek halálának sem napját, sem évét. ${ }^{59}$ Az Érdy-kódexben (MNY 9), melyet a Karthauzi névtelennek tulajdonítanak, magától értetődően szerepel Szent Elek története, a kódex ugyanis legendagyűjtemény. Ezen a változaton különösen érződik a szöveghűségre törekvő igyekezet, a fordító szorosan követi a latin szöveget. Szándéka nem a szórakoztatás volt, elsődleges célja, hogy az olvasót arra indítsa: elmélkedjen a Krisztusért vállalt szenvedésről. Minden bizonnyal ezért hiányoznak a Szent Elek-legendából a hatáskeltő, érzelmes elemek. Talán a magyarázó jelleg miatt maradnak el fontos motívumok is a szövegből, például a gerle-motívum és - meglepő módon - a szent csodái is. A szent halálát a 398. évre teszi, a legendát saját befejezésével zárja. ${ }^{60} \mathrm{~A}$ Kazinczy-kódexben (MNY 11) a Szent Elek-legenda prédikációk és más legendák között szerepel. A fordító láthatóan el tud szakadni a latin eredetitől, így a szöveg mondatai magyaros szerkesztésűek. Költőisége és elbeszélésmódja kiemelkedő, megfogalmazása szemléletes és színes. A Tihanyi-kódexben (MNY 75) az Elek-legendát prédikációba szőve olvashatjuk, maga a kódex is több, Temesvári Pelbárthoz köthető szöveget tartalmaz. A szent élete és tettei a Szent szeretetről szóló prédikáció részévé váltak, így magyarázatot is tartalmaz a szentbeszéd és a legenda közötti kapcsolatról. Annak ellenére, hogy szóbeli közlésre készült szövegről van szó, a fogalmazásmód néhol nehézkes, egyes helyeken pedig meglehetősen latinos stílusú.

Utóbbi két kódex (Kazinczy- és Tihanyi-kódexek) között további, eddig még részleteiben nem kutatott kapcsolatok lehetnek. Ezt bizonyítják a két kódexben megtalálható egy tájegységre utaló tájnyelvi szavak, az íráskép és egyes scriptori közlések. Az Elek-legendákat vizsgálva egyes hiányzó motívumok és cselekményrészletek arra utalhatnak, hogy a két szöveg alkotója, fordítója akár egyazon személy volt, bár ennek ellentmond a két szöveg minőségbeli különbsége.

VI.

A legenda különböző nyelvű változataiban megfigyelhetőek azonos motívumok, amelyeket akár vándormotívumnak is nevezhetünk, mivel sok, ugyanebben a korban lejegyzett és lefordított legendában, történetben megtalálhatóak, sőt, akár más műfajú írásokban, így görög-bizánci regényekben is előfordulnak. Ilyen például az esküvő előtti vagy utáni menekülés. ${ }^{61} \mathrm{~A}$ motívum keletkezésének hátterében több okot is feltéte-

${ }^{59}$ Illés: i. m. (1. jegyz.) 39.

${ }^{60}$ Illés: i. m. (1. jegyz.) 43.

61 J. Weitbrecht: Keuschheit, Ehe und Eheflucht in legendarischen Texten: Vita Malchi, Alexius, Gute Frau. In: W. Röcke - J. Wietbrecht: Askese und Identität in Spätantike, Mittelalter und Früher Neuzeit. Berlin - New York (2010) 133. 
lezhetünk. A kora keresztény időkben az egyház általánosan a szűzies életet ajánlotta életvitelként. ${ }^{62} \mathrm{Az}$ aszkézist, az önmegtartóztatást ugyanis próbatételnek tekintették a szentté válás felé vezető úton. Másfelől azonban a társadalmi elvárás egyik sarokköve a házasság volt, hiszen a nemesség körében ez általános módja volt a családok közti kapcsolatok kiépítésének, ápolásának. A legendairodalom egyik meghatározó jellegzetessége, hogy a szentek példáin épp e két felfogás közötti ellentmondást próbálja bemutatni: miként élnek ők a világban, mit kezdenek a kísértéssel, és hogyan maradnak szüzek a kísértések ellenére is. Az aszketikus életmód ugyanis mindig szembekerül a társadalmi élet elvárásaival, és mindig van egy pont, amely határkőnek bizonyul a kettő között. Ehhez a ponthoz érve a szentek rendre a menekülést választják, hogy saját életfelfogásuk szerint és Istennek tetszően élhessenek. A meneküléssel a társadalmon kívülre helyezik magukat, hogy semmiféle elvárás ne nyomassza őket sem a családjuk, sem a társadalom felől, mint például a családi kötelékek vállalása (akár a hatalom öröklése), a házasság, a gyereknemzés stb. ${ }^{63}$

A meneküléshez vezető események kezdetén a szentet általában kényszeríteni akarják valamire (ez lehet kimondott vagy kimondatlan elvárás is), amely összeegyeztethetetlen a világtól való elvonulással és a lemondással. ${ }^{64} \mathrm{~A}$ szent rövid ideig még beletörődni látszik és engedi, hogy a szülei, a családja a társadalmi életben helyet készítsenek számára, de végül a menekülést választja. Az aszketizmus így nem állapotként, hanem folytonos harcként fogalmazódik meg. A folyamat, amíg a szent eljut a menekülésig, epizódonként jelenik meg a legendákban, a szökést ugyanis nem adott esemény váltja ki, hanem események sorozata, így a sorban utolsó csupán a végpont ahhoz, hogy a szent meghozza elhatározását. Az epizódok bemutatják, miként igyekszik a család a szentet keretek közé szorítani. Jól látható mindez Elek történetében is: kezdetben iskolába adják, hogy tanuljon, nyilvánvalóan abból az elhatározásból, hogy majd követni tudja apját hivatalában. Néhány szöveg azt is megemlíti, hogy Alexios a császár(ok) kedvence: ez is nyomást gyakorolhatott rá, nagy jövőt szánhattak neki. A végső mozzanat a nemes származású leánnyal kötött házassága lesz, amely végül arra indítja őt, hogy elhagyja Rómát.

A menekülésre indító másik ok a szexualitás kérdése. Az önmegtartóztatás ugyanis összeegyeztethetetlen a házassággal és a gyereknemzéssel, a szenttől a társadalmi normák alapján mégis ezt várják el. ${ }^{65} \mathrm{~A}$ szentéletűek ilyen körülmények között is próbálják megtartani tisztaságukat, nem ritka, hogy ennek érdekében akár házastársukat is megtérítik és megnyerik a szűzies élethez. Alexios épp ezt teszi: mielőtt elhagyná Rómát, elbúcsúzik menyasszonyától és - feltehetőleg a szemérmes életről - titkokat oszt meg vele. Ezután, mivel már nem tud az elvárások szerint élni, elhagyja családját, és Istennek szenteli életét.

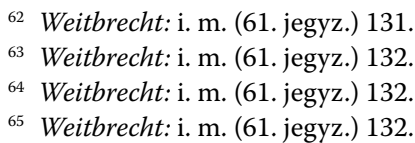


A földrajzi pontossággal ábrázolt menekülést követően a szent, bár egy másik városba, esetleg másik országba érkezik, rövid ideig saját elvárásai és meggyőződése szerint élhet: a helyváltoztatással jelentősen megváltoznak életkörülményei is (Elek, a gazdag szenátor fia rongyokat hord, és alig eszik valamit, koldusként alamizsnát gyűjt), illetve a messzi távolból már a szüzesség és a házasság is összeegyeztethetőnek látszik. Előbb-utóbb viszont ismét összeütközésbe kerül az elvárásokkal, hiszen hiába menekült el otthonából, a társadalom kívánalmai minden emberi közösségben megjelennek. A konfliktusok sorozata újrakezdődik (Alexios esetében ez abban nyilvánul meg, hogy a templomszolga be akarja őt vezetni a templomba, de ez magával hozná a város terhes megbecsülését és tiszteletét), majd abban teljesedik ki, hogy vagy önszántukból, vagy akaratuk ellenére hazatérnek a szülői házba. ${ }^{66}$

A szent ekkor ismét próbatételnek van alávetve, hiszen ismét egy házban él feleségével, tehát mindkét félnek le kell győznie szexuális vágyait, tisztának kell maradniuk, hogy méltók lehessenek Isten országára. A hellénisztikus regényben (amely bizonyos hatással lehetett a legenda gyarapodására és motívumbővülésére) az ilyesféle közelség természetesen a pár egymásra találásával járt volna együtt, míg Alexios történetében a saját családja sem ismeri fel a koldus képében hazatérő férfit. ${ }^{67}$

Azok a tárgyak is figyelemre méltóak, amelyeket Alexios ad át feleségének elutazása elött (gyürü, öv, kendő). Ezeknek a tárgyaknak az átadása sokféle „adást” megjeleníthet: értelmezhető nászajándékként is, a hozomány visszaszolgáltatásaként, búcsúajándékként, az ajándékozóra emlékeztető ajándékként. ${ }^{68}$

A gyürü már a legrégebbi idők óta szinte ugyanazt a jelképet hordozza, anulus fidei vagyis a „hűség gyürűje” értelemben tekintettek rá. Bár Alexios azt a gyürüt adja oda feleségének, amely kettejüket a házasságban összeköti, a gyűrűvisszaadás megszokott értelmezése ellenére nem az eljegyzés vagy házasság felbontásáról van szó. Ebben az esetben a gyűrű a házassági fogadalom megtestesítése mellett a szemérmesség és a szűziesség zálogává is válik. A castitas (tisztaság) magasabb formáját szimbolizálja azáltal, hogy a házasságban megjelenő szűziességet jelenti, sőt, lépcsőfokot a lemondás által történő Krisztus előtti tetszés és az imitatio Christi felé. A frigyben ugyanis nemcsak egymással jegyzik el magukat a felek, hanem a szerzetesi fogadalom mintájára Krisztussal is.

A második tárgyat, az övet egy katonai műszó írja le (renda, balteum militare), tehát feltételezhetjük, hogy olyan övről van szó, amelyre a kardot erősítették, és a katonai felszerelés része volt. Ebben is rejlik szimbolikus jelentés: ha felöltjük magunkra a kardot (természetesen az övvel együtt), akkor beállunk a hadseregbe, ha pedig levesszük, akkor kilépünk onnan. Így Alexios ezzel a mozdulattal jelképesen is visszautasítja, hogy az elvárt kötelezettségeknek megfeleljen, de mindennapi értelemben vett társadalmi szerepet sem fog betölteni, mert ezt a lehetőséget is eltaszítja magától. Más értelmezésben

66 Weitbrecht: i. m. (61. jegyz.) 135.

67 Weitbrecht: i. m. (61. jegyz.) 143.

${ }^{68}$ B. Schmolke-Hassalmann: Ring, Schwert und Gürtel im Albanipsalter. Zeitschrift für französische Sprache und Literatur 87 (1977) 305. 
az öv lehet a szemérmesség, az önmegtartóztatás, a hűség jelképe. Remete szentek ábrázolásain is lehet látni, hogy övet viselnek, amely szexuális önmegtartóztatásukra utal. Nem véletlen, hogy a szerzetességi fogadalmat tevőket a mai napig felövezik a „tisztaság övével”. Ez a tárgy tehát többféleképpen értelmezhető: világi és egyházi/vallási jelentést egyaránt hordoz, Szent Elek esetében valamennyi jelentés megjelenhet. ${ }^{69}$

Alexios felesége, miután férje elhagyta Rómát, önmagát „vadgalambként” jellemzi anyósának. Szándékosan hasonlítja magát a madárhoz, amely a vigasztalhatatlan özvegységet jelképezi. ${ }^{70} \mathrm{~A}$ galamb ugyanis, ha a párja meghal, gyászában az elhagyatott helyeket keresi, nem telepszik meg a zöld lombokban, és nem iszik tiszta forrásból, hanem csupasz faágakon lakik, és pocsolyákból iszik. ${ }^{71}$ Így viselkedik Alexios menyasszonya is: elvonul a világtól, böjtöl és vezekel, hogy a férje visszatérjen hozzá. Ez a gyönyörü hasonlat a legenda valamennyi változatában megtalálható.

VII.

Szent Elek legendája a kora keresztény időktől igen nagy hatású szentélet volt. Népszerűsége nem volt véletlen, hiszen az egyház által támogatott aszketikus és szűzies életről mutatott példát. A legenda bollandistáktól kiadott, általam vizsgált változata is bizonyítja, hogy számos olyan motívumot tartalmaz, amely a kívánt mondandó hangsúlyozására kiválóan alkalmas.

A szír eredetű legenda és annak főhőse Bizáncba kerülése után vált ismertté, majd latin fordítása tette a nyugati egyházi szervezet egyik meghatározó szentjévé. A latin legendát követték az újlatin és egyéb európai népnyelvű szövegek, így megjelenik a középfelnémet, ófrancia, középangol változatok mellett a korai magyar nyelvemlékeink között is. Bár Szent Elek kultusza napjainkra elhomályosult, sok templom és kápolna viseli nevét.

\section{SUMMARY}

The life of Saint Alexius is one of the most famous legends and it is also one of the legends which was translated to many languages during the time of Middle Ages. In this paper I represent the origin of this legend, the general and unique attributes of the multilanguage versions and the Hungarian reception. In my research I was wondering about the popularity of the legend, what presumably can be produced by the common motives and their interpretation, and what motives increased due the time from the earliest Syriac to the first modern language versions.

Keywords: Saint Alexius, legend, Edessa, Arcadios and Honorios, motive, codex

Keresztény Júlia

keresztenyjulia@gmail.com

${ }^{69}$ Schmolke-Hassalmann: i. m. (68. jegyz.) 310.

70 P. S. Allen: Turteltaube. Modern Language Notes 19 (1904) 175.

71 Allen: i. m. (70. jegyz.) 175. 